\title{
Hydrogen peroxide in exhaled air of healthy children: reference values
}

\author{
Q. Jöbsis*, H.C. Raatgeep*, S.L. Schellekens*, W.C.J. Hop**, \\ P.W.M. Hermans*, J.C. de Jongste*
}

Hydrogen peroxide in exhaled air of healthy children: reference values. Q. Jöbsis, H.C. Raatgeep, S.L. Schellekens, W.C.J. Hop, P.W.M. Hermans, J.C. de Jongste. OERS Journals Ltd 1998.

ABSTRACT: An increased content of hydrogen peroxide $\left(\mathrm{H}_{2} \mathrm{O}_{2}\right)$, a marker of inflammation, has been described in the condensate of exhaled air from adults and children with inflammatory lung disorders, including asthma. However, the normal range of $\left[\mathrm{H}_{2} \mathrm{O}_{2}\right]$ in the exhaled air condensate from healthy children has not been established. Therefore, the aim of this study was to determine the reference range of exhaled $\left[\mathrm{H}_{2} \mathrm{O}_{2}\right]$ in healthy school-aged children.

Ninety-three healthy nonsmoking children (48 female and 45 male, mean age 10 yrs, range 8-13 yrs), with a negative history for allergy, eczema or respiratory disease and with a normal lung function, participated. Exhaled air condensate was examined fluorimetrically for the presence of $\mathrm{H}_{2} \mathrm{O}_{2}$. In addition, the reproducibility of $\left[\mathrm{H}_{2} \mathrm{O}_{2}\right]$ within subjects and between days and the stability of $\left[\mathrm{H}_{2} \mathrm{O}_{2}\right]$ during storage at $\mathbf{- 2 0}^{\circ} \mathrm{C}$ were assessed.

The median $\left[\mathrm{H}_{2} \mathrm{O}_{2}\right]$ in the exhaled air condensate of all children was $0.13 \mu \mathrm{M}$, with a $2.5-97.5 \%$ reference range of $<0.01-0.48 \mu \mathrm{M}$. No significant difference existed between males and females. There was no correlation between exhaled $\left[\mathrm{H}_{2} \mathrm{O}_{2}\right]$ and age or lung function. Repeated $\left[\mathrm{H}_{2} \mathrm{O}_{2}\right]$ measurements on 2 consecutive days showed satisfactory within-subject reproducibility and $\left[\mathrm{H}_{2} \mathrm{O}_{2}\right]$ in stored samples remained stable for at least 1 month at $-20^{\circ} \mathrm{C}$.

In conclusion, this study provides reference data for exhaled hydrogen peroxide in a large group of healthy children. The observed levels were lower than those reported previously for healthy adults and were independent of age, sex and lung function. Eur Respir J 1998; 12: 483-485.
*Dept of Paediatrics, Division of Paediatric Respiratory Medicine, and **Dept of Biostatistics, Erasmus University and University Hospital/Sophia Children's Hospital, Rotterdam, The Netherlands.

Correspondence: J.C. de Jongste

Dept of Paediatric Respiratory Medicine

Sophia Children's Hospital

Room Sp-2465

Dr Molewaterplein 60

3015 GJ Rotterdam

The Netherlands

Fax: 31104636801

Keywords: Children

exhaled air

hydrogen peroxide

inflammatory marker

reference values

Received: October 301997

Accepted after revision April 211998

Supported by grant 94.14 from the Netherlands Asthma Fund.
A noninvasive method to assess the presence and activity of airway inflammation would be valuable in the early diagnosis and monitoring of inflammatory airway diseases [1]. Exhaled air condensate can be collected with minimal risk and inconvenience and its content may reflect the com-position of the lower airway fluids [2, 3]. Hydrogen per-oxide $\left(\mathrm{H}_{2} \mathrm{O}_{2}\right)$ in the exhaled air condensate is a potential marker of airway inflammation [4-10]. The only two studies to suggest elevated levels of exhaled $\mathrm{H}_{2} \mathrm{O}_{2}$ in asthmatic children have used small numbers of healthy adults as controls $[4,10]$. The aim of this study was, therefore, to establish reference values of $\left[\mathrm{H}_{2} \mathrm{O}_{2}\right]$ in the exhaled air con-densate of a large group of healthy school-aged children.

\section{Patients and methods}

One hundred and twenty-nine school children, pupils of a primary school, were interviewed with questionnaires on asthma, rhinitis and eczema, translated and validated from the core questionnaires of the International Study of Asthma and Allergy in Childhood (ISAAC). Of these children, 93 had negative questionnaires and were included in the study. Their mean age was 10 yrs (range $8-13$ yrs) and 45 were male (table 1). All were term born, Caucasian lifelong nonsmokers, within the normal range for height, and used no medication. None of the subjects reported symptoms of acute respiratory infection within the previous month. Maximal expiratory flow-volume measurements were performed in all children (Vicatest P2A, Mijnhardt, The Netherlands); forced vital capacity (FVC) and forced expiratory volume in one second (FEV1) were expressed as percentage predicted [11]. Condensate was collected while the children, wearing a noseclip, breathed quietly through a mouthpiece and a two-way nonrebreathing valve (Rudolph,

Table 1. - Characteristics of the study population

\begin{tabular}{lc}
\hline Healthy children $(\mathrm{n}=93)^{*}$ & \\
\hline Age yrs & $10(8-13)$ \\
Sex male/female & $45 / 48$ \\
FVC \% pred & $98 \pm 12$ \\
FEV1 \% pred & $100 \pm 12$ \\
\hline
\end{tabular}

*: all were lifelong nonsmokers, had no symptoms of asthma, eczema or rhinitis, used no medication, and had no symptoms of respiratory infection in the 4 weeks before the study. (range); : mean \pm SD. 
Kansas City, KS, USA), which also served as a saliva trap. At least $1.5 \mathrm{~mL}$ of condensate was obtained by passing expired air through a $50 \mathrm{~cm}$ double jacketed glass tube cooled to $0^{\circ} \mathrm{C}$ and collected on ice. The concentration of $\mathrm{H}_{2} \mathrm{O}_{2}$ in the condensate was determined in duplicate with a fluorimetric assay based on the reaction of $\mathrm{H}_{2} \mathrm{O}_{2}$ with horseradish peroxidase to form a compound which oxidizes $p$-hydroxyphenylacetic acid to a fluorescent product, as described previously [4, 12]. As saliva is a source of $\mathrm{H}_{2} \mathrm{O}_{2}$, the equipment was designed to avoid such contamination, as verified previously by measuring amylase in saliva and breath condensates. Amylase was present in saliva in high concentrations $\left(20,000-300,000 \mathrm{U} \cdot \mathrm{L}^{-1}\right)$, and could never be demonstrated in condensate (invariably $<10$ $\mathrm{U} \cdot \mathrm{L}^{-1}$, unpublished data); therefore, it could be stated with confidence that no contamination with saliva had taken place. To examine the reproducibility of repeated $\mathrm{H}_{2} \mathrm{O}_{2}$ measurements within subjects, condensate was collected from 10 healthy subjects on 2 consecutive days in the morning. To assess the stability of $\left[\mathrm{H}_{2} \mathrm{O}_{2}\right]$ in the frozen condensate, $4 \mathrm{~mL}$ of condensate was collected from 5 subjects. These were divided into $1 \mathrm{~mL}$ aliquots, in which $\mathrm{H}_{2} \mathrm{O}_{2}$ concentrations were determined immediately after collection, after $48 \mathrm{~h}, 1$ week and 1 month of storage at $-20^{\circ} \mathrm{C}$.

\section{Analysis of data}

Results of $\mathrm{H}_{2} \mathrm{O}_{2}$ measurements are expressed as median and range because of an asymmetrical distribution and because some values were below the dection limit. Least squares regression analysis was used to determine possible effects of age or lung function on exhaled $\mathrm{H}_{2} \mathrm{O}_{2}$. Differences between males and females were evaluated with the Mann-Whitney test. Reproducibility was assessed by calculating the mean within-subject difference of two $\mathrm{H}_{2} \mathrm{O}_{2}$ measurements obtained on separate days from 10 subjects and the SD. Stability of $\mathrm{H}_{2} \mathrm{O}_{2}$ in frozen samples was estimated by comparing mean concentrations using a twosided paired t-test, and by calculating mean differences and SD of the differences of immediately determined values and values after a given period of storage. Significance was assumed at $\mathrm{p}<0.05$.

\section{Results}

All subjects had a normal lung function with a mean FVC of $98 \pm 12 \%$ and an FEV1 of $100 \pm 12 \%$. The $\mathrm{H}_{2} \mathrm{O}_{2}$ concentration in the exhaled air condensate ranged from below the detection limit of $0.01 \mu \mathrm{M}$ to $0.50 \mu \mathrm{M}$, with a median value of $0.13 \mu \mathrm{M}$. The 2.5 and 97.5 percentiles were $<0.01$ and $0.48 \mu \mathrm{M}$, respectively. Median $\left[\mathrm{H}_{2} \mathrm{O}_{2}\right]$ from males and females were similar $(0.13 \mu \mathrm{M}$ and $0.14 \mu \mathrm{M}$, respectively, $\mathrm{p}=0.98)$. Individual data of all children are shown in figure 1 . There was no effect of age on $\left[\mathrm{H}_{2} \mathrm{O}_{2}\right](\mathrm{r}=$ $-0.04, \mathrm{p}=0.68$ ). Likewise, no correlation was found between absolute values of $\mathrm{FEV} 1$ and $\left[\mathrm{H}_{2} \mathrm{O}_{2}\right]$ in the condensate $(\mathrm{r}=0.07, \mathrm{p}=0.48)$. Repeated measurements on 2 consecutive days showed a mean within-subject difference of 0.02 $\mu \mathrm{M}$ (sD $0.04 \mu \mathrm{M}$ ). The stability of $\left[\mathrm{H}_{2} \mathrm{O}_{2}\right]$ in frozen condensate was satisfactory, with no significant difference between the $\left[\mathrm{H}_{2} \mathrm{O}_{2}\right]$ immediately after collection $(0.13 \pm 0.03$ $\mu \mathrm{M})$ and after storage at $-20^{\circ} \mathrm{C}$ for $48 \mathrm{~h}(0.11 \pm 0.02 \mu \mathrm{M}$,

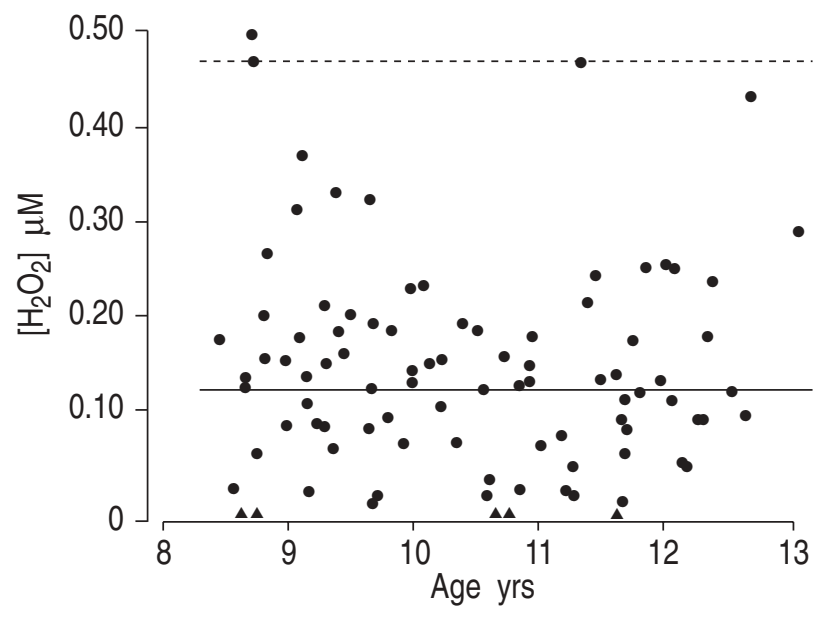

Fig. 1. - Concentration of hydrogen peroxide $\left(\mathrm{H}_{2} \mathrm{O}_{2}\right)$ in the exhaled air condensate of 93 healthy children. The results were independent of age. - - - - : represents the 97.5 percentile upper reference limit $(0.48$ $\mu \mathrm{M})$; and - represents the median $(0.13 \mu \mathrm{M})$. $\mathbf{\Delta}:$ values below the detection limit $(0.01 \mu \mathrm{M})$. Each symbol represents one subject.

$\mathrm{p}=0.14), 1$ week $(0.12 \pm 0.05 \mu \mathrm{M}, \mathrm{p}=0.55)$ and 1 month $(0.13 \pm 0.02 \mu \mathrm{M}, \mathrm{p}=0.59)$.

\section{Discussion}

In this study the reference range of $\mathrm{H}_{2} \mathrm{O}_{2}$ in exhaled air condensate obtained from a large group of healthy schoolaged children has been defined. The methodology was noninvasive and well-tolerated and gave reproducible results. Samples could be stored for at least 1 month and analysed later without changes in $\left[\mathrm{H}_{2} \mathrm{O}_{2}\right]$.

Until now, published data on normal values of $\mathrm{H}_{2} \mathrm{O}_{2}$ concentration in exhaled air were obtained from small numbers of adults [4-6, 8-10]. Peroxide concentrations were observed previously in healthy adults that were higher than the upper limit of the reference range in the present study [4]. This suggests either that healthy children produce less peroxide than adults or that subclinical airway inflammation may be more common in asymptomatic adults than in healthy children. On the basis of these results it can be stated that earlier observations in asthmatic children have indeed shown $\mathrm{H}_{2} \mathrm{O}_{2}$ concentrations in exhaled air that were substantially higher than those found in healthy children $[4,10]$.

In conclusion, this study defined the reference range of hydrogen peroxide, a putative marker of airway inflammation, in exhaled air condensates from a large group of healthy school-aged children. Longitudinal studies are needed to examine the potential value of this inflammatory marker in the management of childhood asthma.

\footnotetext{
Acknowledgement: The authors are indebted to the children and teachers of De Wilgenstam school in Rotterdam who participated in this study.
}

\section{References}

1. O'Byrne PM, Hargreave FE. Non-invasive monitoring of airway inflammation. Am J Respir Crit Care Med 1994; 150: s100-s102. 
2. Scheideler L, Manke HG, Schwulera U, Inacker O, Hämmerle H. Detection of nonvolatile macromolecules in breath; a possible diagnostic tool? Am Rev Respir Dis 1993; 148: 778-784.

3. Becher G, Beck E, Winsel K. Leukotriene $\mathrm{C}_{4}, \mathrm{D}_{4}, \mathrm{E}_{4}, \mathrm{~F}_{4}$ in the breathing condensate of asthmatics in relation to bronchial challenge test. Am J Respir Crit Care Med 1995; 151: A679.

4. Jöbsis Q, Raatgeep HC, Hermans PWM, de Jongste JC. Hydrogen peroxide in exhaled air is increased in stable asthmatic children. Eur Respir J 1997; 10: 519-521.

5. Nowak D, Antczak A, Krol M, et al. Increased content of hydrogen peroxide in the expired breath of cigarette smokers. Eur Respir J 1996; 9: 652-657.

6. Dekhuijzen PNR, Aben KKH, Dekker I, et al. Increased exhalation of hydrogen peroxide in patients with stable and un stable chronic obstructive pulmonary disease. $\mathrm{Am}$ J Respir Crit Care Med 1996; 154: 813-816.

7. Baldwin SR, Grum CM, Boxer LA, Simon RH, Ketai LH, Devall LJ. Oxidant activity in expired breath of patients with adult respiratory distress syndrome. Lancet 1986; 1 :
$11-14$.

8. Kietzmann D, Kahl R, Müller M, Burchardi H, Kettler D. Hydrogen peroxide in expired breath condensate of patients with acute respiratory failure and with ARDS. Inten Care Med 1993; 19: 78-81.

9. Sznajder JI, Fraiman A, Hall JB, et al. Increased hydrogen peroxide in the expired breath of patients with acute hypoxemic respiratory failure. Chest 1989; 96: 606612.

10. Dohlman AW, Black HR, Royall JA. Expired breath hydrogen peroxide is a marker of acute airway inflammation in pediatric patients with asthma. Am Rev Respir Dis 1993; 148: 955-960.

11. Zapletal A, Samanek M, Paul T. Lung function in children and adolescents. Methods, reference values. Basel, Karger, 1987.

12. Hyslop PA, Sklar LA. A quantitative fluorimetric assay for the determination of oxidant production by polymorphonuclear leukocytes: its use in the simultaneous fluorimetric assay of cellular activation processes. Anal Biochem 1984; 141: 280-286. 